\title{
GREENWASHING BEHAVIOURS: CAUSES, TAXONOMY AND CONSEQUENCES BASED ON A SYSTEMATIC LITERATURE REVIEW
}

\author{
Zhi YANG ${ }^{1}$, Thi Thu Huong NGUYEN ${ }^{1,2}{ }^{*}$, Hoang Nam NGUYEN², \\ Thi Thuy Nga NGUYEN ${ }^{1}$, Thi Thanh $\mathrm{CAO}^{3}$ \\ ${ }^{1}$ Business School, Hunan University, 410082 Changsha, PR China \\ ${ }^{2}$ Faculty of Business Administration, Hanoi University of Industry, 100000 Hanoi, Vietnam \\ ${ }^{3}$ Faculty of Tourism, Hanoi University of Industry, 100000 Hanoi, Vietnam
}

Received 15 June 2019; accepted 10 April 2020

\begin{abstract}
This study used the systematic review methodology to examine peer-reviewed journal articles published in the Web of Science, ScienceDirect, Springer and Emerald Insight during the 2000-2020 period to analyse greenwashing. In an open market, the behaviours of state-owned enterprises (SOEs), private firms and multinational corporations (MNCs) pose an implicit greenwashing threat. Our focal point is to analyse corporate greenwashing in MNCs in host emerging markets, particularly in Asia, for two reasons. First, reports of greenwashing have increased around the world since Volkswagen was revealed to have falsified automobile emissions data. Second, MNCs play an important role in expanding market size and their behaviour is increasingly unpredictable. The analysis shows that MNCs tend to engage in greenwashing immediately after doing business in host emerging markets characterised by restricted regulations, clear market opportunities and low competitive pressure. When greenwashing occurs, it will harm the interests of not only consumers, but also society as a whole, despite offering significant benefits to existing stakeholders. In this case, the authorities should implement regulations to confront MNCs before attracting them, which should be enforced in practice.
\end{abstract}

Keywords: green marketing, greenwashing behaviour, environmental performance, corporate communication, corporate social responsibility, business ethics, sustainability.

JEL Classification: D21, D83, F64, L50, M31, O50, Q56.

\section{Introduction}

In recent decades, green marketing has become a highly debated topic for customers, business organisations, shareholders, management and communities (Dangelico \& Vocalelli, 2017). Various green initiatives are available in practice, in diverse areas including energy supply, food, tourism, packaging, fashion, architecture, government and buildings (Leoni-

${ }^{\star}$ Corresponding author. E-mail: thuhuong_mkt@qq.com 
dou \& Skarmeas, 2015). Chen and Chang (2013) argued that green purchasing power forces business organisations to innovate or change their business strategies. Many food companies use greenwashing to appear to be environmentally friendly (Nguyen et al., 2019). Parguel et al. (2011) considered greenwashing as "The act of misleading consumers regarding the environmental practices of a company or the environmental benefits of a product or service". Greenwashing is a well-known way for firms to perform better than their rivals (Parguel et al., 2011). However, almost all critics have agreed that greenwashing is disadvantageous for the environment and consumers' health. For instance, some authors showed the effects of increase in greenwashing and argued that it can negatively affect the confidence of shareholders and consumers in green products (Delmas \& Burbano, 2011; Guo et al., 2018; Pizzetti et al., 2019). Additionally, Ramus and Montiel (2005) and Horiuchi et al. (2009) argued that greenwashing prevents customers from understanding the consequences of their acquisition behaviour when trying to choose between reliable and non-reliable claims. Dahl (2010) suggested that greenwashing is not just a marketing ethic. Perceived greenwashing not only has a negative effect on a company's base channel (Davis, 1992; Du et al., 2018), but green marketing is a market with significant effects. Most recently, Wang et al. (2019) demonstrated the relationship between greenwashing perception of the entire industry and purchase intention of green products from other brands is negatively moderated by brand attitudes towards other brands in the industry. As such, greenwashing has become a hot topic because of its practical importance, increased challenges and research opportunities in different disciplines.

Although previous work has paid attention to issues relevant to greenwashing, few studies to date have focused on greenwashing in MNCs in developing markets, particularly in Asia. The studies of Zhu et al. (2008), Du (2015) and Sun and Zhang (2019) in case of China and Nelson and Robertson (2010) in case of Brazil are typical examples, while almost all other studies have been conducted in Europe or North America. Therefore, this paper attempts to answer the following research questions:

1) What are the conceptual definitions of greenwashing and their evolution over time?

2) What is the taxonomy of greenwashing?

3) How does greenwashing affect behaviour?

4) How to understand and mitigate the causes of greenwashing by MNCs in host developing markets, particularly in Asia?

To this end, the paper is organised as follows. Section 1 presents the methodology. Section 2 highlights the latest definitions and the taxonomy of greenwashing. Section 3 describes greenwashing focusing on MNCs' behaviours. Finally, last Section makes conclusions and directions for future research.

\section{Methodology}

\subsection{Systematic literature review (SLR) method}

This paper used a structured literature review, defined as a systematic, explicit and reproducible design for identifying, evaluating and interpreting the current body of recorded documents (Fink, 2010). A systematic review is an appropriate way to collect a large amount of information (Rodgers et al., 2009) by narrowing down the literature to a particular research 
question. This approach enables reviewers to gain more insight and an in-depth understanding of a topic compared with automatic filtering (Centobelli et al., 2017). Practically, the following steps were conducted:

Step 1: Material collection: identify a list of scientific journals. A literature search was conducted using keywords and established bibliographic database systems.

Step 2: Descriptive analysis: assess the different aspects of the materials, e.g., the distribution over time.

Step 3: Material evaluation: analyse the sample of studies by category. Identify the main issues, results and discussion on directions for future research.

\subsection{Choice of suitable databases and search strategy}

The literature review was performed with articles published in peer-reviewed journals during 2000-2020 period from the ScienceDirect, Emerald Insight, SpringerLink and Web of Science databases. The first search used the term "greenwashing" as a keyword, returning 1,203 articles. Subsequently, it was narrowed down by type of "article" using "greenwashing" keyword, returning 669 articles. Duplicate articles from the databases were ignored. Finally, using advanced search in keywords, article topics, titles and abstracts, 67 potentially relevant articles were obtained when searching for full-text articles. They were carefully analysed and included in the systematic review report analysis. Table 1 shows the search options and the results returned for each database examined.

Table 1. Search options and returned results for each database examined

\begin{tabular}{|l|c|c|c|}
\hline \multicolumn{3}{|c|}{ Search options } \\
\hline Databases & $\begin{array}{l}\text { By keyword } \\
\text { "greenwashing" }\end{array}$ & $\begin{array}{l}\text { 1. By keyword } \\
\text { "greenwashing" } \\
\text { 2. Document type: } \\
\text { Article }\end{array}$ & $\begin{array}{l}\text { 1. By keyword "greenwashing" } \\
\text { 2. Document type: Article } \\
\text { 3. Advanced search: Article topics, } \\
\text { titles, abstracts and keywords }\end{array}$ \\
\hline ScienceDirect & 635 & 451 & 18 \\
\hline Emerald Insight & 106 & 58 & 6 \\
\hline SpringerLink & 409 & 126 & 76 \\
\hline Web of Science & 53 & 34 & 67 \\
\hline Total & 1,203 & 669 & 36 \\
\hline
\end{tabular}

\subsection{Characteristics of the studies}

In this step, 67 academic articles were selected and carefully categorised by keyword search. Subsequently, the researcher conducted a descriptive analysis to assess the different aspects of the materials. Specifically, concept development and conceptual analysis were evaluated, while focusing on the quantitative methods used in empirical research. The last step was to analyse the sample to identify key issues, empirical methods, results and discussion of research directions in the future. Table 2 shows the number and sources of the retrieved articles and Figure 1 illustrates the progression of the number of studies during the study period. 


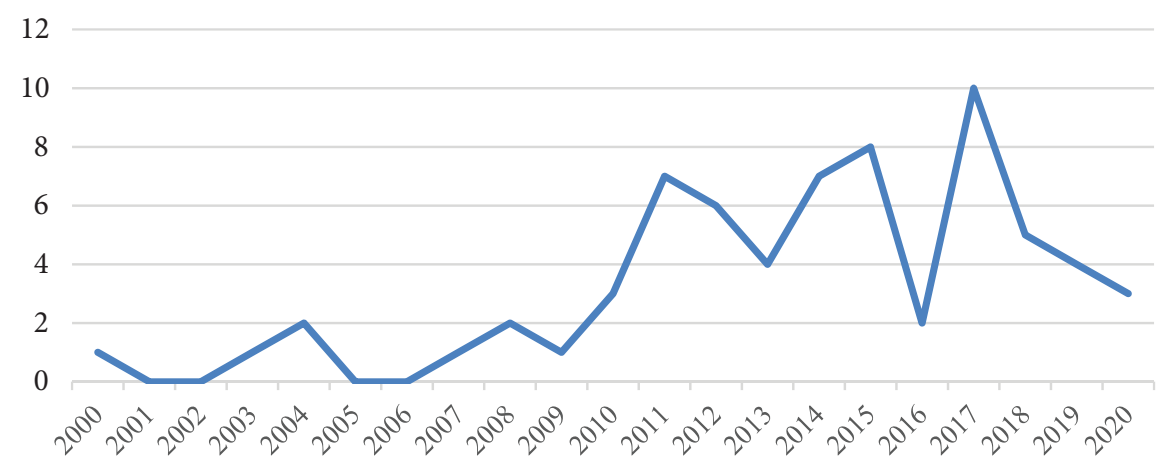

Figure 1. Progression of the number of articles or studies during our study period

Table 2 reports the journals titles in which articles reviewed were published. As shown, the Journal of Business Ethics published the most studies on greenwashing, followed by the Journal of Cleaner Production. The 67 articles retrieved were published in 38 journals.

Table 2. Number of retrieved articles

\begin{tabular}{|l|c|}
\hline \multicolumn{1}{|c|}{ Journal title } & Quantity \\
\hline Business Horizons & 1 \\
\hline California Management Review & 1 \\
\hline Corporate Governance: The International Journal of Business in Society & 1 \\
\hline Development & 1 \\
\hline Energy Policy & 1 \\
\hline Environment and Planning & 1 \\
\hline Environmental and Resource Economics & 2 \\
\hline Environmental Health Perspectives & 1 \\
\hline Environmental History & 1 \\
\hline Environmental Sciences Europe & 1 \\
\hline Global Environmental Change & 1 \\
\hline Industrial and Commercial Training & 1 \\
\hline International Journal of Contemporary Hospitality Management & 1 \\
\hline International Journal of Global Environmental Issues & 1 \\
\hline International Journal of Hospitality Management & 2 \\
\hline International Political Sociology & 1 \\
\hline Journal of Global Responsibility & 1 \\
\hline Journal of Business Ethics & 16 \\
\hline Journal of Business Research & 1 \\
\hline Journal of Cleaner Production & 8 \\
\hline Journal of Economics and Management Strategy & 1 \\
\hline Journal of Environmental Economics and Management & 1 \\
\hline & 1 \\
\hline
\end{tabular}


End of Table 2

\begin{tabular}{|l|c|}
\hline \multicolumn{1}{|c|}{ Journal title } & Quantity \\
\hline Journal of European Public Policy & 1 \\
\hline Journal of Organizational Change Management & 1 \\
\hline Journal of Regulatory Economics & 2 \\
\hline Journal of Sustainable Tourism & 1 \\
\hline Marine Policy & 1 \\
\hline Marketing Intelligence and Planning & 3 \\
\hline Meditari Accountancy Research & 1 \\
\hline Organization and Environment & 3 \\
\hline Organization Science & 1 \\
\hline Portland International Conference on Management of Engineering and Technology & 1 \\
\hline Quality and Quantity & 1 \\
\hline Research in International Business and Finance & 1 \\
\hline Review of Agricultural Economics & 1 \\
\hline Social Responsibility Journal & 1 \\
\hline Sustainability & 1 \\
\hline Tourism Management & 1 \\
\hline Total & 67 \\
\hline
\end{tabular}

Previous researchers reviewed and analysed articles published until 2000. There was no study in our databases in the following four years: 2001, 2002, 2005 and 2006. In 2010, the number of articles started to increase, reaching the maximum number of 10 articles in 2017. Figure 2 shows the different countries involved. We found that various authors conducted an investigation in Western, United States and multiple countries, but few studies focused on emerging Asian economies.

Table 3 provides a summary of the topic and related description of the articles. One third focused on the perceived importance of marketing. They discussed the relationship between greenwashing and a variety of specific topics as green confidence, brand image, eco-labels, green brand loyalty, green scepticism and green word-of-mouth (Ulusoy \& Barretta, 2016; Lin et al., 2017; Zhang et al., 2018; Nguyen et al., 2019). Public policies and environmental

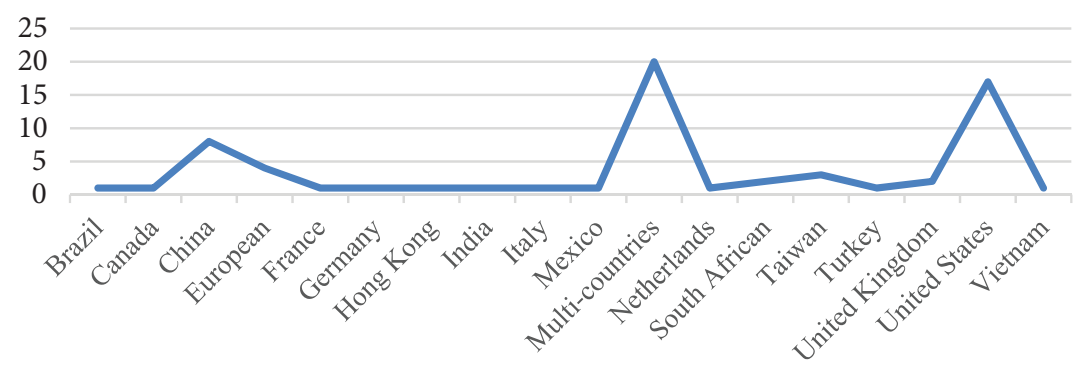

Figure 2. Countries studied and number of articles on greenwashing 
management were the second major topic. Most discussions focused on greenwashing in corporate environmentalism practices and the issue of politics (Luke, 2008; Coates et al., 2011; Harris, 2015; Alons, 2017; Sun \& Zhang, 2019). Besides, a variety of other topics were examined as corporate communication, environmental issues, corporate social responsibility (CSR), accounting and finance, business ethics and education (Ackers, 2009; Jones, 2012; Ariztía et al., 2014; Kim \& Lyon, 2015; Rahman et al., 2015; Du et al., 2018; Uyar et al., 2020; Yu et al., 2020).

Table 3. Summary of identified topics and related description

\begin{tabular}{|c|c|c|c|}
\hline Area of study & $\begin{array}{l}\text { Number of } \\
\text { articles }\end{array}$ & Authors & Related description \\
\hline Marketing & 23 & $\begin{array}{l}\text { Lim (2011), Delmas and Burbano } \\
\text { (2011), Chen and Chang (2013), } \\
\text { Chan (2013), Smith and Font (2014), } \\
\text { Chen et al. (2014), Nyilasy et al. } \\
\text { (2014), Leonidou and Skarmeas } \\
\text { (2015), Lyon and Montgomery } \\
\text { (2015), Ulusoy and Barretta (2016), } \\
\text { Blome et al. (2017), Siano et al. } \\
\text { (2017), Chen et al. (2017), Lin et al. } \\
\text { (2017), Brécard (2017), Guo et al. } \\
\text { (2018), Zhang et al. (2018), Akturan } \\
\text { (2018), Pizzetti et al. (2019), Chen } \\
\text { et al. (2019), Nguyen et al. (2019), } \\
\text { Wang et al. (2019), De Freitas Netto } \\
\text { et al. (2020) }\end{array}$ & $\begin{array}{l}\text { The relationship between } \\
\text { greenwashing and a } \\
\text { variety of specific topics, } \\
\text { such as green confidence, } \\
\text { brand image, eco-labels, } \\
\text { green brand loyalty, green } \\
\text { skepticism, green word-of- } \\
\text { mouth, green purchasing } \\
\text { intention and in the supply- } \\
\text { chain }\end{array}$ \\
\hline $\begin{array}{l}\text { Corporate } \\
\text { commu- } \\
\text { nication }\end{array}$ & 8 & $\begin{array}{l}\text { Kim and Lyon (2011), Parguel et al. } \\
\text { (2011), Walker and Wan (2012), Lyon } \\
\text { and Montgomery (2013), Bowen and } \\
\text { Aragon-Correa (2014), Kim and Lyon } \\
\text { (2015), Du (2015), Yu et al. (2020) }\end{array}$ & $\begin{array}{l}\text { Corporate environmental } \\
\text { practices and sustainability } \\
\text { disclosure }\end{array}$ \\
\hline $\begin{array}{l}\text { Public } \\
\text { policies and } \\
\text { environmental } \\
\text { management }\end{array}$ & 14 & $\begin{array}{l}\text { Kirchhoff (2000), Cliath (2007), Luke } \\
\text { (2008), Solomon and Rhianon Pel } \\
\text { Edgley (2008), Coates et al. (2011), } \\
\text { Matisoff (2012), Matejek and Gössling } \\
\text { (2014), Berrone et al. (2015), Harris } \\
\text { (2015), Guo et al. (2017), Ramesh and } \\
\text { Rai (2017), Alons (2017), Testa et al. } \\
\text { (2018), Sun and Zhang (2019) }\end{array}$ & $\begin{array}{l}\text { The issue of politics and } \\
\text { environmental actions, the } \\
\text { government regulation of } \\
\text { companies' greenwashing } \\
\text { behaviours }\end{array}$ \\
\hline $\begin{array}{l}\text { Environmental } \\
\text { issues }\end{array}$ & 7 & $\begin{array}{l}\text { Lightfoot and Burchell (2004), Nelson } \\
\text { and Robertson (2010), Stephenson } \\
\text { et al. (2012), Mccrory and Langvardt } \\
\text { (2012), Gamper-Rabindran and } \\
\text { Finger (2013), Geerts (2014), Rahman } \\
\text { et al. (2015) }\end{array}$ & $\begin{array}{l}\text { Sustainable development and } \\
\text { greenwashing actions }\end{array}$ \\
\hline $\begin{array}{l}\text { Corporate } \\
\text { social } \\
\text { responsibility }\end{array}$ & 8 & $\begin{array}{l}\text { Hamann and Kapelus (2004), Ackers } \\
\text { (2009), Holme (2010), Font et al. } \\
\text { (2012), Roulet and Touboul (2015), } \\
\text { Wang and Sarkis (2017), Gosselt et al. } \\
\text { (2017), Uyar et al. (2020) }\end{array}$ & $\begin{array}{l}\text { Corporate sustainability and } \\
\text { ethics issue }\end{array}$ \\
\hline
\end{tabular}


End of Table 3

\begin{tabular}{|l|c|l|l|}
\hline Area of study & $\begin{array}{l}\text { Number of } \\
\text { articles }\end{array}$ & \multicolumn{1}{|c|}{ Authors } & \multicolumn{1}{|c|}{ Related description } \\
\hline $\begin{array}{l}\text { Accounting } \\
\text { and finance }\end{array}$ & 4 & $\begin{array}{l}\text { Laufer (2003), Relaño (2011), Lyon } \\
\text { and Maxwell (2011), Du et al. (2018) }\end{array}$ & $\begin{array}{l}\text { Financial greenwashing and } \\
\text { corporate environmental } \\
\text { performance }\end{array}$ \\
\hline Business ethics & 2 & Dahl (2010), Ariztía et al. (2014) & $\begin{array}{l}\text { The effect of greenwashing } \\
\text { on marketing ethics }\end{array}$ \\
\hline $\begin{array}{l}\text { Education and } \\
\text { sustainable } \\
\text { development }\end{array}$ & 1 & Jones (2012) & $\begin{array}{l}\text { Sustainable universities' } \\
\text { greenwashing behaviour }\end{array}$ \\
\hline
\end{tabular}

\section{Definitions and taxonomy of greenwashing}

\subsection{Definitions}

The term "greenwashing" was coined by New York environmentalist Jay Westervelt in 1986 (Romero, 2008). Few authors subsequently referred to greenwashing and the term only became popular after 1996 when the concept was introduced in a book on environmental marketing (Greer \& Bruno, 1996). Then, the literature on this issue has significantly increased. Some scholars have derived this term from the Oxford English Dictionary as 'disinformation disseminated by an organisation so as to present an environmentally responsible public image (Ramus \& Montiel, 2005; Gillespie, 2008; Mitchell \& Ramey, 2011; Wang \& Sarkis, 2017). The general use of the term, and even the academic debate about it, seems to be broad and vague. International scholars and experts have found different definitions of greenwashing in different fields. To facilitate this interdisciplinary debate, Table 4 presents some main definitions of greenwashing. Delmas and Burbano (2011) defined the term as poor environmental performance and positive communication about environmental performance. This definition assumes that it is possible to summarise a firm's environmental performance and to classify it as negative or positive. Similarly, a firm's communication can be summarised as positive or negative. Lyon and Maxwell (2011) proposed a clearer explanation, suggesting that greenwashing refers to the selective disclosure of positive information about a company's social or environmental actions, without a complete negative revelation, to produce an overly positive corporate image. However, this understanding is strictly related to the 'hard' disclosure of confirmable information on environmental performance and ignores phenomena such as image advertising, visual imagery and vague claims. Walker and Wan (2012) defined greenwashing as a gap between "symbolic" and "substantive" corporate social actions. Management scholars have for long contrasted different forms of corporation social actions: to respond to institutional pressure, firms can substantively comply with imposed norms, or pretend to do so.. Other academics have used the definition proposed by Greenpeace, defining greenwashing as "the act of misleading consumers regarding the environmental practices of a company or the environmental benefits of a product or service" (Romero, 2008). Mitchell and Ramey (2011) indicated that the "act" of greenwashing must be deliberate. Thus, greenwashing is an intentional deceit (Nyilasy et al., 2014). Bowen and Aragon-Correa (2014) considered 
greenwashing as "a specific subset of symbolic corporate environmentalism in which the changes are both 'merely symbolic' and deliberately so". A new challenge is to go beyond current conceptions of greenwashing to analyse environmentally symbolic corporations (Rivera et al., 2014; Roulet \& Touboul, 2015). Previous studies have often assumed that greenwashing involves aspects such as information disclosure decision that are deliberate and initiated by companies and beneficial for them, but costly to society. This understanding is useful as it helps researchers model and measure greenwashing in empirical studies (Lyon \& Maxwell, 2011; Barrage et al., 2014; Du, 2015).

Table 4. Some main definitions

\begin{tabular}{|l|l|l|}
\hline \multicolumn{1}{|c|}{ Definitions } & \multicolumn{1}{|c|}{ Authors } & \multicolumn{1}{|c|}{ Year } \\
\hline $\begin{array}{l}\text { "Selective disclosure of positive information about a company's } \\
\text { environmental or social performance without full disclosure of } \\
\text { negative information on these dimensions, so as to create an overly } \\
\text { positive corporate image". }\end{array}$ & $\begin{array}{l}\text { Lyon and } \\
\text { Maxwell }\end{array}$ & 2011, p. 9 \\
\hline $\begin{array}{l}\text { "The act of misleading consumers regarding the environmental } \\
\text { practices of a company or the environmental benefits of a product or } \\
\text { service". }\end{array}$ & $\begin{array}{l}\text { Parguel et al., } \\
\text { Chen and } \\
\text { Chang }\end{array}$ & $\begin{array}{l}\text { 2011, p. } 15 \\
\text { 2013, p. } 489\end{array}$ \\
\hline $\begin{array}{l}\text { "Poor environmental performance and positive communication about } \\
\text { environmental performance". }\end{array}$ & $\begin{array}{l}\text { Delmas and } \\
\text { Burbano }\end{array}$ & 2011, p. 65 \\
\hline $\begin{array}{l}\text { "Symbolic information emanating from within an organization } \\
\text { without substantive actions". }\end{array}$ & $\begin{array}{l}\text { Walker and } \\
\text { Wan }\end{array}$ & 2012, p. 231 \\
\hline $\begin{array}{l}\text { "A specific subset of symbolic corporate environmentalism in which } \\
\text { the changes are both 'merely symbolic' and deliberately so". }\end{array}$ & $\begin{array}{l}\text { Bowen and } \\
\text { Aragon- } \\
\text { Correa }\end{array}$ & 2014, p. 3 \\
\hline
\end{tabular}

\subsection{The taxonomy of greenwashing}

Besides four known types of greenwashing (firm-level executional, firm-level claim, productlevel executional, and product-level claim) (De Freitas Netto et al., 2020), this paper identified six types of greenwashing, using academic work as examples. There is no confirmation that the provided list is complete, as previous studies are not developed enough to ensure all variations are recognised. In addition, the list appears to be mutually exclusive because the content of the report published annually by a firm can contain selective disclosure of confirmable information, a story and pictures. Nevertheless, these types of greenwashing are theoretically different.

\subsubsection{Selective disclosure}

This type of greenwashing has been the most studied in greenwashing research. Surprisingly, the conflicting outcomes are mainly due to the way a firm discloses information (Font et al., 2012; Zhang et al., 2018; Nguyen et al., 2019; Wang et al., 2019). Corporations with poor environmental performance based on toxic emissions tended to disclosure at higher levels (Patten, 2002). In contrast, few authors indicated that firms disclosed more if they had better environmental performance (Clarkson et al., 2008; Du et al., 2018; Uyar et al., 2020). 
Philippe and Durand (2011) concluded that a firm's reputation improved immediately after the publication of a sustainability report, even though it did not come into effect in practice, except in case of environmentally friendly firms whose reputation might be improved if substantial improvements were reported (Philippe \& Durand, 2011). Kim and Lyon (2011) pointed out that a firm's emissions disclosure was a type of greenwashing, as corporations did not disclose a decrease in their carbon footprint, while they usually disclosed an increase in their carbon footprint.

\subsubsection{Decoupling}

Meyer and Rowan (1977) extended these early studies by conceptualising a more institutional account of decoupling. Decoupling occurs when companies claim to meet the expectations of their shareholders, without really changing their practices. It usually happens when an organisation encourages ambitious justifiable projects without the support of sufficient sustainable units or sufficient funds to achieve the desired corporate objectives (Meyer \& Rowan, 1977; Bromley \& Powell, 2012; Ariztía et al., 2014). Therefore, greenwashing is a decoupling strategy to achieve legitimacy and indicate compliance without strictly conforming (Delmas \& Burbano, 2011; Berrone et al., 2015). In addition, in recent studies, Guo et al. (2017) suggested that the term "decoupling" comes from organisational theory.

\subsubsection{Attention deflection}

Attention deflection refers to symbolic activities designed to deflect the attention of stakeholders to hide corrupt business actions (Brown \& Dacin, 1997; Lightfoot \& Burchell, 2004; Marquis \& Toffel, 2012; Guo et al., 2018). It involves various communication strategies that include selective and incorrect disclosure (Cho \& Patten, 2007; Lyon \& Maxwell, 2011; Mccrory \& Langvardt, 2012; Geerts, 2014), as unfinished assessments or vague and incorrect statements (TerraChoice, 2009). In addition, another method of diverting attention in CSR communication is undefined disclosure, which occurs when corporations highlight the importance of a product, without explanation (Snyder, 1989; Relaño, 2011; Gamper-Rabindran \& Finger, 2013) or in the absence of detailed information and trustworthy accreditations, approved by a third party (Matejek \& Gössling, 2014; Yu et al., 2020).

\subsubsection{Deceptive manipulation}

The fourth type of greenwashing is also called deceptive handling. It implies misleading conduct in which sustainable communication creates a deliberate operation of business practices to promote the perception that a firm's products, aims and/or policies are environmentally friendly (Blome et al., 2017; Siano et al., 2017; Pizzetti et al., 2019).

\subsubsection{Dubious authorisations and labels}

Authorisation to external parties that define standards is usually considered as greenwashing, replacing the trustworthiness of a third-party authoriser with a firm's own rights. However, while authorisations at the product and company levels are designed to control greenwashing, they cannot prevent the phenomenon themselves. Firms lobby for the introduction of a third-party eco-labelling system or stricter labelling rules (Smart, 1992). One possible 
problem is that eco-labels can be susceptible to fraud by dishonest manufacturers (Hamilton \& Zilberman, 2006; Stephenson et al., 2012; Chan, 2013; Nguyen et al., 2019). Therefore, under certain conditions, the environmental authorisations of companies can take the form of greenwashing (Kirchhoff, 2000; Brécard, 2017; Lin et al., 2017; De Freitas Netto et al., 2020).

\subsubsection{Inefficient public voluntary programmes}

Companies contribute to government-funded voluntary programmes for many reasons, but their contribution alone cannot bring about environmental improvements (Hamann \& Kapelus, 2004; Matisoff, 2012; Smith \& Font, 2014). For example, early contributors to the Energy Policy Act of the Climate Leaders programme reduced their carbon 19 footprint more than non-contributors, but those who joined later did not (Delmas \& Montes-Sancho, 2010). This suggests that those who joined later contributed in the form of greenwashing. The efficiency of public voluntary programmes depends on strict regulations and the imposition of fines on newcomers who do not comply with the standards (Henriques et al., 2013).

\section{Greenwashing behaviours}

\subsection{Causes of greenwashing}

State-owned enterprises (SOEs), private firms and MNCs are three types of businesses operating in emerging markets, as shown in Figure 3. Among them, the role of MNCs is very important as being partners in investment capital and technology transfer. The overall effect of MNCs on emerging markets has been overwhelmingly positive, despite the persistence of policies with negative or unintended consequences.

One of the main positive effects of MNCs on host markets is to improve living standard, benefitting to consumers by lowering prices, increasing product quality and expanding selection range. Additionally, MNCs have a significant effect on domestic firms' business practices and help developing economies to participate in the globalisation process. However, their behaviours represent an implicit threat of greenwashing, as external environmental factors are not strong enough to deal with. Greenwashing is currently increasing around the world, raising the question of how to mitigate this negative trend. To this end, we should examine three main causes of greenwashing.

\subsubsection{Governmental policies}

In recent years, environmental safety rules have been put in place. However, environmental regulations are not well applied $(\mathrm{Du}, 2015)$ and many firms misuse greenwashing to look environmentally friendly. Government rules related to environment may contain governance strategies and principles that range from strategic facts involving environmental specialists (Zhu et al., 2008; Walls \& Hoffman, 2013) to operational issues, as the integration of environmental accounting, management systems, green supply chains (Henri \& Journeault, 2010), the government punishment and government tax subsidy mechanisms (Sun \& Zhang, 2019). Companies can apply these government mechanisms for many reasons, including meeting environmental regulatory requirements, exceeding competitive benchmarks and improving 
the company's reputation (Holme, 2010; Archel et al., 2011; Contrafatto, 2014). Nevertheless, these authorised resource allocations cannot guarantee the development of more environmentally friendly products (Christmann \& Taylor, 2006; Boiral \& Henri, 2012). The government plays a major role in business operations. The extent of this role varies from country to country and industry to industry. In host emerging markets, there are restricted regulations on greenwashing but uncertain implementation. Therefore, MNCs can use greenwashing if their operations are governed by profit maximisation.

\subsubsection{Competitive pressure}

In fact, many firms apply greenwashing to project an environmentally friendly reputation or/and image. Therefore, greenwashing is a general technique that allows institutions to get ahead of their opponents (Parguel et al., 2011). Firms often interact with their rivals in product market to win over consumers and increase their market share or even fight for their survival (Testa et al., 2018). The behaviour of a firm is affected by competitive pressure via certain channels through actions undertaken by other firms to reach the same group of consumers in the market. Greenwashing is a phenomenon linked to scandals that often occur at the supply-chain level (Pizzetti et al., 2019). Remarkably, MNCs often face lower competitive pressure when operating in host emerging markets in the early stage for following reasons.

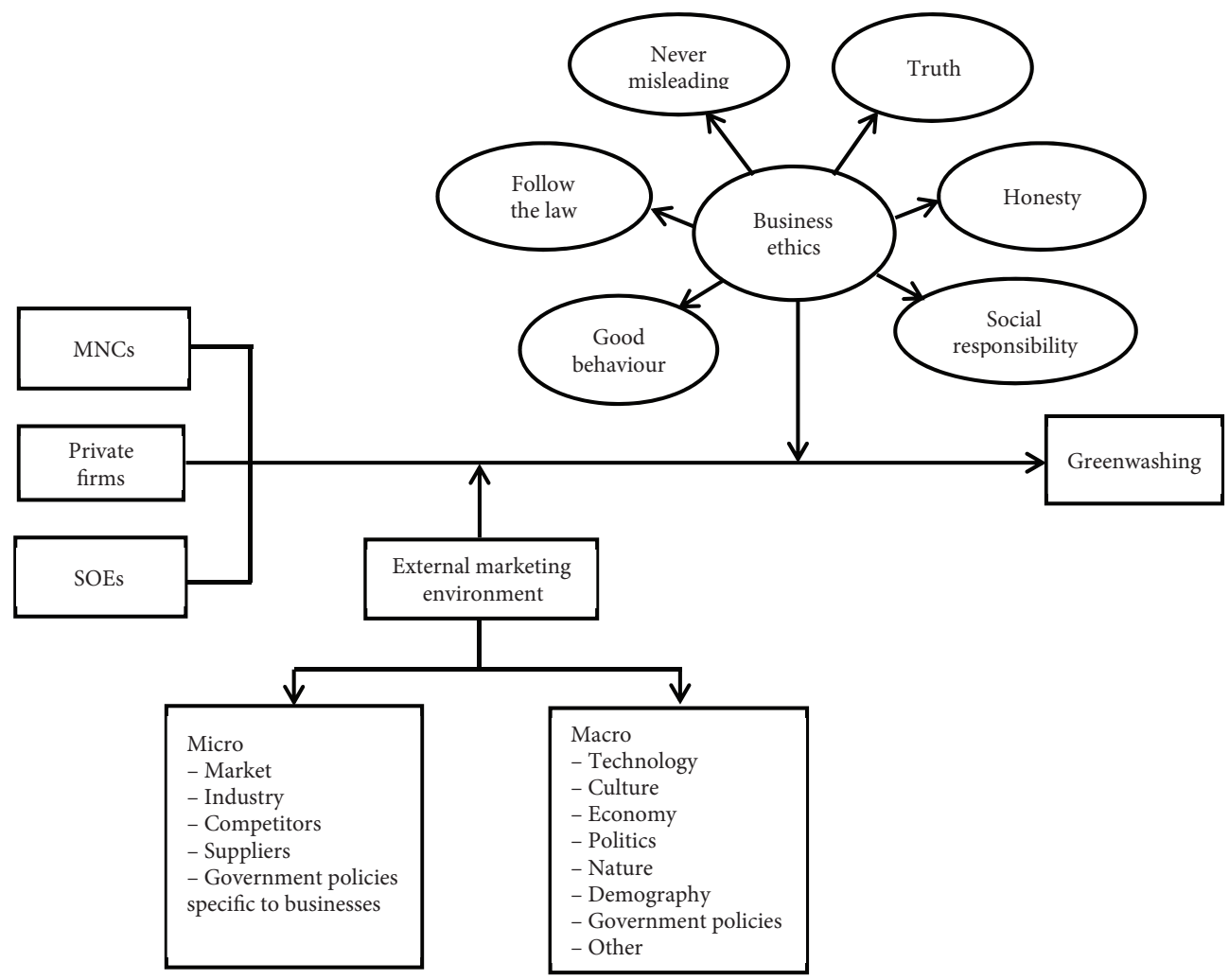

Figure 3. The sources of greenwashing 
First, host countries open their markets to welcome foreign investors to solve the shortage of domestic investments. Second, MNCs have great comparative advantages over domestic firms in terms of technology, capital investment, labour quality and management skills.

\subsubsection{Market opportunities}

Market opportunities are identified by a new demand that a firm can meet, as it is not supplied by competitors. MNCs have great market opportunities as they often produce products that either serve a new market or respond to a growing demand from domestic market segment that is not satisfied by others. Due to growing concern over global warming, customers have become more environmentally aware (Lu et al., 2008; Chen \& Chang, 2012). Corporations use greenwashing to attract green consumers and increase positive word-of-mouth (Laufer, 2003; Parguel et al., 2011). Greenwashing has become common for corporations to take advantage of these market opportunities (Horiuchi et al., 2009).

In summary, Figure 3 illustrates the causes of greenwashing used by three types of corporations in host emerging markets. As discussed above, the business environment of MNCs is characterised by clear market opportunities, low competitive pressure and restricted regulations on greenwashing. In other words, MNCs do not strictly adhere to the six sins of business ethics, leading to greenwashing. If this is the case, the disadvantages will not only fall on consumers, but also on society as a whole, and MNCs will benefit from greenwashing in an unfair way. The following sections further analyse the consequences of greenwashing on different market players.

\subsection{Consequences of greenwashing}

If corporations practise CSR, it will increase their attractiveness to specific stakeholders, leading to positive consumer orientation and purchase intentions (Jamali \& Karam, 2018). However, corporate greenwashing, especially that of MNCs, has a negative effect not only on consumers, but also on potential stakeholders. However, the effect on stakeholders is more complex because there are two types of stakeholders, namely existing and potential stakeholders. For existing stakeholders, greenwashing will have a positive effect through additional profits (Solomon \& Rhianon Pel Edgley, 2008). But in this case, greenwashing negatively affects society as a whole, which is demonstrated by the deadweight loss in welfare economics. The second group consists of determined potential stakeholders, as investors who wish to participate in the production of real green products and the implementation of CSR. Greenwashing prevents potential stakeholders from investing in a firm that produces environmentally friendly products. After greenwashing, brand trust between green brands and their stakeholders can suffer a great deal of damage (Guo et al., 2018). If greenwashing is not prevented in time, its consequences become extreme in the long term, as fewer investors or stakeholders are willing to invest in production of green products for a market. In turn, it encourages firms to engage in harmful behaviours. This means that behaviours have negative externalities and thus negatively affect social welfare. The paper outlines the consequences of greenwashing for consumers, corporations, stakeholders and society in details hereafter. 


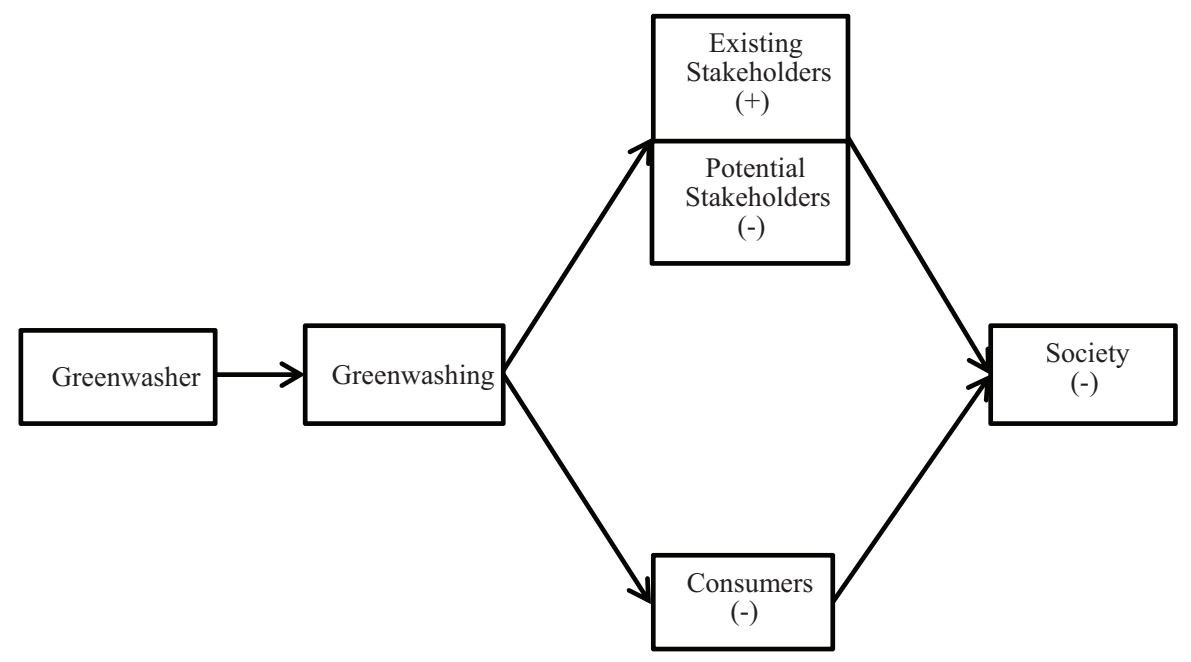

Figure 4 . The consequences of greenwashing

\subsubsection{Consumers}

Greenwashing has become commonplace among firms, with a strong negative effect on consumers of green products (Delmas \& Burbano, 2011; Lim, 2011). Greenwashing behaviour of one brand even negatively affects consumers' purchase intention of the green products from other brands in the industry (Wang et al., 2019). First, greenwashing leads to information overload, making it difficult for customers to evaluate products (Walsh et al., 2007; Gosselt et al., 2017). Second, consumers may behave in a dubious way as they realise the difference between a firm's performance and its green advertising (Nyilasy et al., 2014). Consumers may negatively understand the reasons behind a company's secret motives (Cliath, 2007). Therefore, consumers are becoming increasingly sceptical about companies taking advantage of the environmental trend (Pomering \& Johnson, 2009; Nguyen et al., 2019). Finally, Nyilasy et al. (2014) argued that greenwashing is not just a moral issue. Consumers have some knowledge of greenwashing, which significantly affects their brand attitude, green branding equity and buying intent (Akturan, 2018; Zhang et al., 2018; Nguyen et al., 2019).

\subsubsection{Corporations}

Corporations often benefit from greenwashing. Under the cumulative pressure of shareholders and environmentalists, some corporations adopt greenwashing behaviour to develop an environmentally friendly image and/or reputation. However, greenwashing can change the role of corporate performance in the environmental inspection process as well as the association between CSR performance and CSR reporting (Uyar et al., 2020). Therefore, greenwashing behaviours may lead workers to lose confidence in their company based of unconfirmed claims, making them nervous as indisposed participants (Walker \& Wan, 2012). Furthermore, it can lead to a loss of confidence among consumers, investors and non-governmental organisations (Painter-Morland, 2006; Jahdi \& Acikdilli, 2009; Lyon \& Montgomery, 2015). Greenwashing produces a crisis of belief and can even result in a loss of brand equity (Guo 
et al., 2017). Greenwashing is an obstacle to expanding green marketing approaches, also negatively associated with green brand image, green satisfaction and green brand equity (Chen et al., 2017).

\subsubsection{Stakeholders}

Greenwashing has become a common practice in the circumstance of marketing and corporate communication strategies, in order to fulfil the promises made to stakeholders and meet their expectations (Delmas \& Burbano, 2011; Seele \& Gatti, 2015; Guo et al., 2018). First, greenwashing is tactical in the way of misinforming shareholders about the real social performance of a company. This strategy can activate stakeholder support, but with little investment in corporate social actions (Husted \& Allen, 2009). Stakeholders often lack sufficient information to assess the environmental footprint of different companies (Busch \& Hoffmann, 2009; Lyon \& Maxwell, 2011; Pizzetti et al., 2019). Second, investors and the community rely on advertising, but greenwashing behaviours betray their belief. Additionally, other corporations may lose confidence in a greenwashing firm (King \& Lenox, 2000), reducing their likelihood of cooperating and exchanging resources with this firm. By forming a partnership with a greenwashing company, they may fear being identified as greenwashers themselves, further increasing their desire to avoid this company. The outcome is that greenwashing endangers investor confidence and provokes negative market feedback. Finally, if the environmental, social, and governance information disclosed by firms is not reliable, a firm's greenwashing behaviour can be a barrier to integrating the environmental, social, and governance factors into investment decisions (Yu et al., 2020). The effect of greenwashing on the relationships with these stakeholders will eventually lead to a decline in financial performance, detrimental to investment (Pizzetti et al., 2019).

\subsubsection{Society}

Greenwashing can undermine confidence in a firm's environmental effects (Hsu, 2011). Some studies suggested that exposure to greenwashing can lead to increased consumer cynicism and mistrust (Jahdi \& Acikdilli, 2009; Chen et al., 2019; Nguyen et al., 2019). Parguel et al. (2011) argued that exposure also confuses consumers about a firm's claims and its motives for making such claims. Figure 4 indicates that greenwashing negatively affects consumer benefits while increasing shareholders' interest in most cases. Even if shareholder benefits outweigh the loss of consumers, the benefits of society as a whole will be reduced, which can clearly be seen from the perspective of resource allocation and social welfare (Ramesh \& Rai, 2017). This further demonstrates that regulators need to intervene to mitigate the negative consequences of greenwashing for society as a whole (Sun \& Zhang, 2019; Yu et al., 2020; Uyar et al., 2020).

\section{Discussion}

Due to the contradictions between environmental protection and profit maximization, many companies use greenwashing to appear to be environmentally friendly. This paper argues 
that the definitions of greenwashing given by Lyon and Maxwell (2011) and Parguel et al. (2011) are the most relevant to what is happening in emerging Asian economies. Among six sins of greenwashing, selective disclosure seems to be a preferred way to describe MNCs' greenwashing in host emerging market. Thus, this broad view of greenwashing encourages further discussion of this phenomenon in these countries.

This article pays special attention on analyzing the causes and consequences of greenwashing among MNCs in host developing markets, particularly in Asia. With regard to the causes of greenwashing, while the effects of MNCs on emerging markets has been overwhelmingly positive, their behaviours represent an implicit threat of greenwashing, as external environmental factors are not strong enough to deal with. The clear market opportunities, low competitive pressure and restricted regulations lead to greenwashing is currently increasing around the world. This is increasingly severe problem needs to be solved urgently. Further, the recent of Volkswagen scandal and a phenomenon that is linked to scandals that often occur at the supply-chain level, suggesting that greenwashing behaviour is very subtle and diffused (Siano et al., 2017; Pizzetti et al., 2019; Wang et al., 2019). In this circumstance, a more effort need to study the causes of greenwashing and its different steps. Concerning the consequences of greenwashing, some aspects have not been dealt with and should be deepened. The effect of greenwashing behaviours on stakeholders is more complex because there are existing and potential stakeholders, and stakeholders at all the supply-chain level. This review highlights that future research should be deeply understanding about the consequences of greenwashing in various industries from difference aspects.

\section{Conclusions}

The paper identifies the risk of greenwashing by MNCs in host emerging markets, particularly in Asia. Greenwashing can occur immediately when MNCs do not strictly follow business ethics because of the immature legal framework in host countries. The business environment of Asian host economies is characterised by clear market opportunities and low competitive pressure, especially in the early stage of industrialization. This is the time when greenwashing is most likely to appear. Greenwashing always hurts society's benefits, even if it brings significant interests to existing stakeholders. In this case, the main role of the government or authorities is to protect customers. Therefore, the paper emphasised on the decisive role of micro and macro policies and/or regulations made by host governments and their strict implementation by the competent authorities in practice to mitigate the negative consequences of greenwashing.

Similar to others, this paper has some limitations. We analysed many social science articles based on developed Western countries. This limitation provides an opportunity to extend research to developing countries in the world and in Asia where greenwashing is likely to appear, especially in the early phase of industrialization. Certainly, this important work should be pursued by researchers in the future. 


\section{References}

Ackers, B. (2009). Corporate social responsibility assurance: How do South African publicly listed companies compare? Meditari Accountancy Research, 17, 1-17. https://doi.org/10.1108/10222529200900009

Akturan, U. (2018) How does greenwashing affect green branding equity and purchase intention? An empirical research. Marketing Intelligence \& Planning, 36, 809-824. https://doi.org/10.1108/MIP-12-2017-0339

Alons, G. (2017). Environmental policy integration in the EU's common agricultural policy: Greening or greenwashing? Journal of European Public Policy, 24(11), 1604-1622. https://doi.org/10.1080/13501763.2017.1334085

Archel, P., Husillos, J., \& Spence, C. (2011). The institutionalisation of unaccountability: Loading the dice of Corporate Social Responsibility discourse. Accounting Organizations \& Society, 36, 327-343. https://doi.org/10.1016/j.aos.2011.06.003

Ariztía, T., Kleine, D., Brightwell, M. D. G. S. L., Agloni, N., Afonso, R., \& Bartholo, R. (2014). Ethical consumption in Brazil and Chile: institutional contexts anddevelopment trajectories. Journal of Cleaner Production, 63, 84-92. https://doi.org/10.1016/j.jclepro.2013.04.040

Barrage, L., Chyn, E., \& Hastings, J. (2014). Advertising, reputation, and environmental stewardship: Evidence from the BP oil spill. Social Science Electronic Publishing. https://doi.org/10.3386/w19838

Berrone, P., Fosfuri, A., \& Gelabert, L. (2015). Does greenwashing pay off? Understanding the relationship between environmental actions and environmental legitimacy. Journal of Business Ethics, 144, 1-17. https://doi.org/10.1007/s10551-015-2816-9

Blome, C., Kai, F., \& Schleper, M. C. (2017). Antecedents of green supplier championing and greenwashing: An empirical study on leadership and ethical incentives. Journal of Cleaner Production, 152, 339-350. https://doi.org/10.1016/j.jclepro.2017.03.052

Boiral, O., \& Henri, J. F. (2012). Modelling the impact of ISO 14001 on environmental performance: a comparative approach. Journal of Environmental Management, 99, 84-97. https://doi.org/10.1016/j.jenvman.2012.01.007

Bowen, F., \& Aragon-Correa, J. A. (2014). Greenwashing in corporate environmentalism research and practice: The importance of what we say and do. Organization \& Environment, 27, 107-112. https://doi.org/10.1177/1086026614537078

Brécard, D. (2017). Consumer misperception of eco-labels, green market structure and welfare. Journal of Regulatory Economics, 51, 340-364. https://doi.org/10.1007/s11149-017-9328-8

Bromley, P.,\& Powell, W. W. (2012). From smoke and mirrors to walking the talk: Decoupling in the contemporary world. Academy of Management Annals, 6, 483-530. https://doi.org/10.5465/19416520.2012.684462

Brown, T. J., \& Dacin, P. A. (1997). The company and the product: Corporate associations and consumer product responses. Journal of Marketing, 61, 68-84. https://doi.org/10.1177/002224299706100106

Busch, T., \& Hoffmann, V. H. (2009). Ecology-driven real options: An investment framework for incorporating uncertainties in the context of the natural environment. Journal of Business Ethics, 90(2), 295-310. https://doi.org/10.1007/s10551-009-0043-y

Centobelli, P., Cerchione, R., \& Esposito, E. (2017). Environmental sustainability in the service industry of transportation and logistics service providers: Systematic literature review and research directions. Transportation Research Part D Transport \& Environment, 53, 454-470. https://doi.org/10.1016/j.trd.2017.04.032

Chan, E. S. W. (2013). Managing green marketing: Hong Kong hotel managers' perspective. International Journal of Hospitality Management, 34, 442-461. https://doi.org/10.1016/j.ijhm.2012.12.007 
Chen, H., Bernard, S., \& Rahman, I. (2019). Greenwashing in hotels: A structural model of trust and behavioral intentions. Journal of Cleaner Production, 206, 326-335.

https://doi.org/10.1016/j.jclepro.2018.09.168

Chen, Y. S., \& Chang, C. H. (2012). Enhance green purchase intentions: The roles of green perceived value, green perceived risk, and green trust. Management Decision, 50, 502-520. https://doi.org/10.1108/00251741211216250

Chen, Y. S., \& Chang, C. H. (2013). Greenwash and green trust: The mediation effects of green consumer confusion and green perceived risk. Journal of Business Ethics, 114, 489-500. https://doi.org/10.1007/s10551-012-1360-0

Chen, Y. S., Lin, C. L., \& Chang, C. H. (2014). The influence of greenwash on green word-of-mouth (green WOM): the mediation effects of green perceived quality and green satisfaction. Quality \& Quantity, 48, 2411-2425. https://doi.org/10.1007/s11135-013-9898-1

Chen, Y. S., Tien, W. P., Lee, Y. I., \& Tsai, M. N. (2017). Greenwash and green brand equity. In Portland International Conference on Management of Engineering and Technology (pp. 1797-1803). https://doi.org/10.1109/PICMET.2016.7806783

Cho, C. H., \& Patten, D. M. (2007). The role of environmental disclosures as tools of legitimacy: A research note. Accounting Organizations \& Society, 32, 639-647. https://doi.org/10.1016/j.aos.2006.09.009

Christmann, P., \& Taylor, G. (2006). Firm self-regulation through international certifiable standards: determinants of symbolic versus substantive implementation. Journal of International Business Studies, 37, 863-878. https://doi.org/10.1057/palgrave.jibs.8400231

Clarkson, P. M., Li, Y., Richardson, G. D., \& Vasvari, F. P. (2008). Revisiting the relation between environmental performance and environmental disclosure: An empirical analysis. Accounting Organizations \& Society, 33(4-5), 303-327. https://doi.org/10.1016/j.aos.2007.05.003

Cliath, A. G. (2007). Seeing shades: Ecological and socially just labeling. Organization \& Environment, 20, 413-439. https://doi.org/10.1177/1086026607309406

Coates, P., Cole, T., Dudley, M., \& Pearson, C. (2011). Defending nation, defending nature? Militarized landscapes and military environmentalism in Britain, France, and the United States. Environmental History, 16(3), 456-491. https://doi.org/10.1093/envhis/emr038

Contrafatto, M. (2014). The institutionalization of social and environmental reporting: An Italian narrative. Accounting Organizations \& Society, 39, 414-432. https://doi.org/10.1016/j.aos.2014.01.002

Dahl, R. (2010). Green washing: Do you know what you're buying? Environmental Health Perspectives, 118, A246. https://doi.org/10.1289/ehp.118-a246

Dangelico, R. M., \& Vocalelli, D. (2017). “Green Marketing”: An analysis of definitions, strategy steps, and tools through a systematic review of the literature. Journal of Cleaner Production, 165, 12631279. https://doi.org/10.1016/j.jclepro.2017.07.184

Davis, J. J. (1992). Ethics and environmental marketing. Journal of Business Ethics, 11, 81-87. https://doi.org/10.1007/BF00872314

De Freitas Netto, S. V., Sobral, M. F. F., Ribeiro, A. R. B., \& Soares, G. R. D. L. (2020) Concepts and forms of greenwashing: a systematic review. Environmental Sciences Europe, 32, 19. https://doi.org/10.1186/s12302-020-0300-3

Delmas, M. A., \& Burbano, V. C. (2011). The drivers of greenwashing. California Management Review, 54, 64-87. https://doi.org/10.1525/cmr.2011.54.1.64

Delmas, M. A., \& Montes-Sancho, M. J. (2010). Voluntary agreements to improve environmental quality: symbolic and substantive cooperation. Strategic Management Journal, 31, 575-601. https://doi.org/10.1002/smj.826

$\mathrm{Du}, \mathrm{X}$. (2015). How the market values greenwashing? Evidence from China. Journal of Business Ethics, 128, 547-574. https://doi.org/10.1007/s10551-014-2122-y 
Du, X., Jian, W., Zeng, Q., \& Chang, Y. (2018). Do auditors applaud corporate environmental performance? Evidence from China. Journal of Business Ethics, 151, 1049-1080. https://doi.org/10.1007/s10551-016-3223-6

Fink, A. (2010). Conducting research literature reviews: from the Internet to paper. Journal of Advanced Nursing, 55, 792-792. https://doi.org/10.1111/j.1365-2648.2006.04033.x

Font, X., Walmsley, A., Cogotti, S., McCombes, L., \& Häusler, N. (2012). Corporate social responsibility: the disclosure-performance gap. Tourism Management, 33(6), 1544-1553. https://doi.org/10.1016/j.tourman.2012.02.012

Gamper-Rabindran, S., \& Finger, S. R. (2013). Does industry self-regulation reduce pollution? Responsible Care in the chemical industry. Journal of Regulatory Economics, 43, 1-30. https://doi.org/10.1007/s11149-012-9197-0

Geerts, W. (2014). Environmental certification schemes: hotel managers' views and perceptions. International Journal of Hospitality Management, 39, 87-96. https://doi.org/10.1016/j.ijhm.2014.02.007

Gillespie, E. (2008). Stemming the tide of 'Greenwash'. Consumer Policy Review, 18(3), 79-83.

Gosselt, J. F., Rompay, T. V., \& Haske, L. (2017). Won't get fooled again: The effects of internal and external CSR eco-labeling. Journal of Business Ethics, 2, 1-12. https://doi.org/10.1007/s10551-017-3512-8

Greer, J., \& Bruno, K. (1996). Greenwash: the reality behind corporate environmentalism. Multinational Monitor, 30(9).

Guo, R., Tao, L., Li, C. B., \& Wang, L. (2017). A path analysis of greenwashing in a trust crisis among Chinese energy companies: The role of brand legitimacy and brand loyalty. Journal of Business Ethics, 140, 523-536. https://doi.org/10.1007/s10551-015-2672-7

Guo, R., Zhang, W., Wang, T., Li, C. B., \& Tao, L. (2018). Timely or considered? Brand trust repair strategies and mechanism after greenwashing in China-from a legitimacy perspective. Industrial Marketing Management, 72, 127-137. https://doi.org/10.1016/j.indmarman.2018.04.001

Hamann, R., \& Kapelus, P. (2004). Corporate social responsibility in mining in Southern Africa: Fair accountability or just greenwash? Development, 47, 85-92. https://doi.org/10.1057/palgrave.development.1100056

Hamilton, S. F., \& Zilberman, D. (2006). Green markets, eco-certification, and equilibrium fraud. Journal of Environmental Economics \& Management, 52, 627-644. https://doi.org/10.1016/j.jeem.2006.05.002

Harris, P. (2015). Militarism in environmental disguise: The greenwashing of an overseas military base. International Political Sociology, 9, 19-36. https://doi.org/10.1111/ips.12074

Henri, J. F., \& Journeault, M. (2010). Eco-control: The influence of management control systems on environmental and economic performance. Accounting Organizations \& Society, 35, 63-80. https://doi.org/10.1016/j.aos.2009.02.001

Henriques, I., Husted, B. W., \& Montiel, I. (2013). Spillover Effects of voluntary environmental programs on greenhouse gas emissions: Lessons from Mexico. Journal of Policy Analysis \& Management, 32, 296-322. https://doi.org/10.1002/pam.21675

Holme, C. (2010). Corporate social responsibility: a strategic issue or a wasteful distraction? Industrial \& Commercial Training, 42, 179-185. https://doi.org/10.1108/00197851011048528

Horiuchi, R., Schuchard, R., Shea, L., \& Townsend, S. (2009). Understanding and preventing greenwash. A business guide. Business for Social Responsibility, London, UK.

Hsu, T. (2011). Skepticism grows over products touted as eco-friendly. Los Angeles Times. http://articles.latimes.com/2011/may/21/business/la-fi-greenwash-20110521

Husted, B. W., \& Allen, D. B. (2009). Strategic corporate social responsibility and value creation: A study of multinational enterprises in Mexico. Management International Review, 49, 781-799.

https://doi.org/10.1007/s11575-009-0016-5 
Jahdi, K. S., \& Acikdilli, G. (2009). Marketing communications and Corporate Social Responsibility (CSR): Marriage of convenience or shotgun wedding? Journal of Business Ethics, 88, 103-113. https://doi.org/10.1007/s10551-009-0113-1

Jamali, D., \& Karam, C. (2018). Corporate social responsibility in developing countries as an emerging field of study. International Journal of Management Reviews, 20, 32-61.

https://doi.org/10.1111/ijmr.12112

Jones, D. R. (2012). Looking through the "greenwashing glass cage" of the green league table towards the sustainability challenge for UK universities. Journal of Organizational Change Management, 25, 630-647. https://doi.org/10.1108/09534811211239263

Kim, E. H., \& Lyon, T. P. (2011). Strategic environmental disclosure: Evidence from the DOE's voluntary greenhouse gas registry. Journal of Environmental Economics \& Management, 61, 311-326. https://doi.org/10.1016/j.jeem.2010.11.001

Kim, E. H., \& Lyon, T. P. (2015). Greenwash vs. brownwash: Exaggeration and undue modesty in corporate sustainability disclosure. Organization Science, 26, 705-723. https://doi.org/10.1287/orsc.2014.0949

King, A. A., \& Lenox, M. J. (2000). Industry self-regulation without sanctions: The chemical industry's responsible care program. Academy of Management Journal, 43, 698-716. https://doi.org/10.2307/1556362

Kirchhoff, S. (2000). Green business and blue angels. Environmental \& Resource Economics, 15, 403-420. https://doi.org/10.1023/A:1008303614250

Laufer, W. S. (2003). Social accountability and corporate greenwashing. Journal of Business Ethics, 43, 253-261. https://doi.org/10.1023/A:1022962719299

Leonidou, C. N., \& Skarmeas, D. (2015). Gray shades of green: Causes and consequences of green skepticism. Journal of Business Ethics, 144, 401-415. https://doi.org/10.1007/s10551-015-2829-4

Lightfoot, S., \& Burchell, J. (2004). Green hope or greenwash? The actions of the European Union at the World Summit on sustainable development. Global Environmental Change, 14, 337-344. https://doi.org/10.1016/j.gloenvcha.2004.07.002

Lim, W. M. (2011). Green marketing: issues, developments and avenues for future research. International Journal of Global Environmental Issues, 11, 139-156. https://doi.org/10.1504/IJGENVI.2011.043509

Lin, J., Lobo, A., \& Leckie, C. (2017). Green brand benefits and their influence on brand loyalty. Marketing Intelligence \& Planning, 35, 425-440. https://doi.org/10.1108/MIP-09-2016-0174

Lu, J., Chen, G., \& Frierson, D. (2008). Response of the zonal mean atmospheric circulation to El Nino versus global warming. Journal of Climate, 21, 5835. https://doi.org/10.1175/2008JCLI2200.1

Luke, T. W. (2008). The politics of true convenience or inconvenient truth: struggles over how to sustain capitalism, democracy, and ecology in the 21st century. Environment \& Planning A, 40, 1811-1824. https://doi.org/10.1068/a40158

Lyon, T. P., \& Maxwell, J. W. (2011). Greenwash: Corporate environmental disclosure under threat of audit. Journal of Economics \& Management Strategy, 20, 3-41. https://doi.org/10.1111/j.15309134.2010.00282.x

Lyon, T. P., \& Montgomery, A. W. (2013). Tweetjacked: The impact of social media on corporate greenwash. Journal of Business Ethics, 118, 747-757. https://doi.org/10.1007/s10551-013-1958-x

Lyon, T. P., \& Montgomery, A. W. (2015). The means and end of greenwash. Organization \& Environment, 28, 21-36. https://doi.org/10.1177/1086026615575332

Marquis, C., \& Toffel, M. W. (2012). When do firms greenwash? Corporate visibility, civil society scrutiny, and environmental disclosure. Social Science Electronic Publishing.

Matejek, S., \& Gössling, T. (2014). Beyond legitimacy: A case study in BP’s "green lashing". Journal of Business Ethics, 120, 571-584. https://doi.org/10.1007/s10551-013-2006-6 
Matisoff, D. C. (2012). Privatizing climate change policy: Is there a public benefit? Environmental \& Resource Economics, 53, 409-433. https://doi.org/10.1007/s10640-012-9568-0

Mccrory, M. A., \& Langvardt, K. T. (2012). Cutting out the middle-man: The case for direct business involvement in environmental justice. Business Horizons, 55, 357-362. https://doi.org/10.1016/j.bushor.2012.02.005

Meyer, J. W., \& Rowan, B. (1977). Institutionalized organizations: Formal structure as myth and ceremony. American Journal of Sociology, 83, 340-363. https://doi.org/10.1086/226550

Mitchell, L. D., \& Ramey, W. D. (2011). Look how green i am! An Individual-level explanation for greenwashing. Journal of Applied Business \& Economics, 12, 40-45.

Nelson, G. C., \& Robertson, R. D. (2010). Green gold or green wash: Environmental consequences of biofuels in the developing world. Review of Agricultural Economics, 30, 517-529. https://doi.org/10.1111/j.1467-9353.2008.00426.x

Nguyen, T. T. H., Yang, Z., Nguyen, N., Johnson, L. W., \& Cao, T. K. (2019). Greenwash and green purchase intention: The mediating role of green skepticism. Sustainability, 11, 2653. https://doi.org/10.3390/su11092653

Nyilasy, G., Gangadharbatla, H., \& Paladino, A. (2014). Perceived greenwashing: The interactive effects of green advertising and corporate environmental performance on consumer reactions. Journal of Business Ethics, 125, 693-707. https://doi.org/10.1007/s10551-013-1944-3

Painter-Morland, M. (2006). Triple bottom-line reporting as social grammar: integrating corporate social responsibility and corporate codes of conduct. Business Ethics A European Review, 15, 352-364. https://doi.org/10.1111/j.1467-8608.2006.00457.x

Parguel, B., Benoît-Moreau, F., \& Larceneux, F. (2011). How sustainability ratings might deter 'greenwashing': A closer look at ethical corporate communication. Journal of Business Ethics, 102, 15-28. https://doi.org/10.1007/s10551-011-0901-2

Patten, D. M. (2002). The relation between environmental performance and environmental disclosure: a research note. Accounting Organizations \& Society, 27, 763-773.

https://doi.org/10.1016/S0361-3682(02)00028-4

Philippe, D., \& Durand, R. (2011). The impact of norm - conforming behaviors on firm reputation. Strategic Management Journal, 32, 969-993. https://doi.org/10.1002/smj.919

Pizzetti, M., Gatti, L., \& Seele, P. (2019). Firms Talk, suppliers walk: Analyzing the locus of greenwashing in the blame game and introducing 'vicarious greenwashing. Journal of Business Ethics. https://doi.org/10.1007/s10551-019-04406-2

Pomering, A., \& Johnson, L. W. (2009). Constructing a corporate social responsibility reputation using corporate image advertising. Australasian Marketing Journal, 17, 106-114. https://doi.org/10.1016/j.ausmj.2009.05.006

Rahman, I., Park, J. D., \& Chi, G. Q. C. (2015). Consequences of "greenwashing”: consumer's reactions to hotel's green initiatives. International Journal of Contemporary Hospitality Management, 27, 1054-1081. https://doi.org/10.1108/IJCHM-04-2014-0202

Ramesh, M., \& Rai, N. D. (2017). Trading on conservation: A marine protected area as an ecological fix. Marine Policy, 82, 25-31. https://doi.org/10.1016/j.marpol.2017.04.020

Ramus, C. A., \& Montiel, I. (2005). When are corporate environmental policies a form of greenwashing? Business \& Society, 44, 377-414. https://doi.org/10.1177/0007650305278120

Relaño, F. (2011). Maximizing social return in the banking sector. Corporate Governance International Journal of Business in Society, 11, 274-284. https://doi.org/10.1108/14720701111138698

Rivera, J., Bowen, F. E., Delmas, M., et al. (2014). After greenwashing: New directions on the symbol and substance of environmental responsiveness. Academy of Management Annual Meeting Proceedings, 2014, 11858-11858. https://doi.org/10.5465/ambpp.2014.11858symposium 
Rodgers, M., Sowden, A., Petticrew, M., Arai, L., Roberts, H., Britten, N., \& Popay, J. (2009). Testing methodological guidance on the conduct of narrative synthesis in systematic reviews effectiveness of interventions to promote smoke alarm ownership and function. Evaluation, 15(1), 49-73. https://doi.org/10.1177/1356389008097871

Romero, P. (2008). Beware of green marketing, warns Greenpeace exec. ABS-CBN. www.abs-cbnnews. com/special-report/09/16/08/beware-green-marketing-warns-greenpeace-exec

Roulet, T. J., \& Touboul, S. (2015). The intentions with which the road is paved: Attitudes to liberalism as determinants of greenwashing. Journal of Business Ethics, 128, 305-320. https://doi.org/10.1007/s10551-014-2097-8

Seele, P., \& Gatti, L. (2015). Greenwashing revisited: In search of a typology and accusation-based definition incorporating legitimacy strategies. Business Strategy \& the Environment, 26(2). https://doi.org/10.1002/bse.1912

Siano, A., Vollero, A., Conte, F., \& Amabile, S. (2017). "More than words": Expanding the taxonomy of greenwashing after the Volkswagen scandal. Journal of Business Research, 71, 27-37. https://doi.org/10.1016/j.jbusres.2016.11.002

Smart, B. (1992). Beyond compliance - a new industry view of the environment. World Resources Institute.

Smith, V. L., \& Font, X. (2014). Volunteer tourism, greenwashing and understanding responsible marketing using market signalling theory. Journal of Sustainable Tourism, 22, 942-963. https://doi.org/10.1080/09669582.2013.871021

Snyder, R. (1989). Misleading characteristics of implied-superiority claims. Journal of Advertising, 18, 54-61. https://doi.org/10.1080/00913367.1989.10673167

Solomon, J. F., \& Rhianon Pel Edgley, C. (2008). The abandoned mandatory OFR: a lost opportunity for SER? Social Responsibility Journal, 4, 324-348. https://doi.org/10.1108/17471110810892848

Stephenson, E., Doukas, A., \& Shaw, K. (2012). “Greenwashing gas: Might a 'transition fuel' label legitimize carbon-intensive natural gas development?”. Energy Policy, 46, 452-459.

https://doi.org/10.1016/j.enpol.2012.04.010

Sun, Z., \& Zhang, W. (2019). Do government regulations prevent greenwashing? An evolutionary game analysis of heterogeneous enterprises. Journal of Cleaner Production, 231, 1489-1502. https://doi.org/10.1016/j.jclepro.2019.05.335

TerraChoice. (2009). The seven sins of greenwashing. TerraChoice Environmental Marketing Inc., Ottawa, ON.

Testa, F., Boiral, O., \& Iraldo, F. (2018). Internalization of environmental practices and institutional complexity: Can stakeholders pressures encourage greenwashing? Journal of Business Ethics, 147, 287-307. https://doi.org/10.1007/s10551-015-2960-2

Ulusoy, E., \& Barretta, P. G. (2016). How green are you, really? Consumers' skepticism toward brands with green claims. Journal of Global Responsibility, 7. https://doi.org/10.1108/JGR-11-2015-0021

Uyar, A., Karaman, A. S., \& Kilic, M. (2020). Is corporate social responsibility reporting a tool of signaling or greenwashing? Evidence from the worldwide logistics sector. Journal of Cleaner Production, 253, 119997. https://doi.org/10.1016/j.jclepro.2020.119997

Walker, K., \& Wan, F. (2012). The harm of symbolic actions and green-washing: Corporate actions and communications on environmental performance and their financial implications. Journal of Business Ethics, 109, 227-242. https://doi.org/10.1007/s10551-011-1122-4

Walls, J. L., \& Hoffman, A. J. (2013). Exceptional boards: Environmental experience and positive deviance from institutional norms. Journal of Organizational Behavior, 34, 253-271.

https://doi.org/10.1002/job.1813 
Walsh, G., Hennig-Thurau, T., \& Mitchell, V. (2007). Consumer confusion proneness: scale development, validation, and application. Journal of Marketing Management, 23, 697-721. https://doi.org/10.1362/026725707X230009

Wang, H., Ma, B., \& Bai, R. (2019). The spillover effect of greenwashing behaviours: An experimental approach. Marketing Intelligence \& Planning, 38(3), 283-295. https://doi.org/10.1108/MIP-01-2019-0006

Wang, Z., \& Sarkis, J. (2017). Corporate social responsibility governance, outcomes, and financial performance. Journal of Cleaner Production, 162, 1607-1616. https://doi.org/10.1016/j.jclepro.2017.06.142

Yu, E. P.-y., Luu, B. V., \& Chen, C. H. (2020). Greenwashing in environmental, social and governance disclosures. Research in International Business and Finance, 52, 101192. https://doi.org/10.1016/j.ribaf.2020.101192

Zhang, L., Li, D., Cao, C., \& Huang, S. (2018). The influence of greenwashing perception on green purchasing intentions: The mediating role of green word-of-mouth and moderating role of green concern. Journal of Cleaner Production, 187, 740-750. https://doi.org/10.1016/j.jclepro.2018.03.201

Zhu, Q., Sarkis, J., Cordeiro, J. J., \& Lai, K.-H. (2008). Firm-level correlates of emergent green supply chain management practices in the Chinese context. Omega, 36, 577-591.

https://doi.org/10.1016/j.omega.2006.11.009 